\title{
Corporate Governance, Karakteristik Perusahaan dan Kinerja Perusahaan
}

Submitted Date:

3 April 2021

Accepted Date:

26 April 2021
Rahmat Setiawan

Universitas Airlangga

rahmatsetiawan@feb.unair.ac.id

Ivone Dona Khoirun Nisa

Universitas Airlangga

ivone.dona.khoirun-2020@feb.unair.ac.id

Suggested Citation:

Bennedsen, M., Kongsted, H. C., \& Nielsen, K. M. (2008). The causal effect of board size in the performance of small and medium-sized firms. Journal of Banking and Finance, 32(6), 1098-1109. https://doi.org/10.1016/j.jbankfin.2007.09.016

Abstract:

The purpose of this research is to determine and explain the influence of corporate governance and firm characteristics on firm performance. This research uses manufacturing companies as samples and the number of observations is 228. Multiple linear regression testing is used as a method for research. The results show that corporate governance proxied by proportion of independent commissioners, company characteristics proxied by leverage and company size shows that both simultaneously and partially have an effect on company performance.

Keywords: Corporate Governace, Firm Characteristic, Firm Performance

Abstrak:

Penelitian ini memiliki tujuan untuk mengetahui pengaruh corporate governance dan karakteristk perusahaan terhadap kinerja perusahaan. Perusahaan manufaktur digunakan sebagai sampel dan jumlah observasi sebanyak 228. Pengujian regresi linear berganda digunakan sebagai metode penelitian. Hasil regresi menunjukkan, proporsi komisaris independen yang merupakan ukuran corporate governance, leverage dan ukuran perusahaan yang merupakan ukuran karaketristik perusahaan secara simultan maupun parsial memiliki pengaruh terhadap kinerja perusahaan.

Kata kunci: Corporate Governance, Karakteristik Perusahaan, Kinerja Perusahaan

JEL Classification : M10 


\section{Latar Belakang}

Beberapa skandal - skandal keuangan yang terjadi di hampir seluruh negara terutama di Asia Tenggara telah menibulkan krisis moneter dan menghancurkan kinerja perusahaan. Salah satu faktor penyebab skandal dan krisis moneter yakni minimnya penerapan Good Corporate Governance yang tercermin dengan kurangnya akuntabilitas, transparansi, keteraturan hukum serta peran stakeholders dalam menilai kebijaksanaan yang dilakukan perusahaan. Corporate governance diperlukan untuk mengelola perusahaan agar lebih baik karena melibatkan pemeriksaan-pemeriksaan dan keseimbangan yang diperlukan untuk mencegah penyalahgunaan oleh orang dalam. Jika hukum, peraturan dan praktik-praktik bisnis berfungsi dengan baik maka perusahaan dapat mengelola hubungan antar investor maupun stakeholder sehingga produktivitas dan kinerja perusahaan akan meningkat (Hasnati, 2003).

Keadaan lain yang merupakan latar belakang dari perlunya corporate governace adalah berkaitan dengan persoalan yang timbul dari dalam perusahaan yakni pemisahan antara pemegang saham sebagai pemilik dengan manajemen yang bertugas mengelola perusahaan. Adanya teori agensi yang memisahkan kepemilikan dan pengelolaan menjadikan kepentingan pemilik modal menjadi terancam. Hal ini dikarenakan pengelola umumnya menggunakan laba yang diperoleh dari kegiatan operasional untuk kepentingannya sendiri, bukan untuk meningkatkan kekayaan pemegang saham dan perusahaan. Salah satu upaya meminimalisir terulangnya skandal keuangan adalah dengan penerapan good corporate governance. Penunjukan komisaris dan komisaris independen yang tugasnya yakni melakukan pengawasan atau monitoring dan pemberian nasihat terhadap proses pengambilan keputusan oleh direksi adalah contoh bentuk aplikasi good corporate governance di perusahaan publik.

Selain itu, kinerja perusahaan juga erat kaitannya dengan karakteristik perusahaan. Perusahaan membutuhkan modal yang cukup untuk mendanai investasi yang layak untuk meningkatkan kinerja perusahaan. Sumber pendanaan yang muncul dapat diperoleh dari pendanaan intenal yakni dengan menggunakan laba ditahan maupun pendanaan eksternal yakni dengan utang. Leverage terjadi bilamana perusahaan dalam mendanai baik dalam hal operasional perusahaan dan investasi pada suatu proyek menggunakan sumber dana yang menimbulkan beban keuangan yang tetap yakni utang (Sudana, 2015:180). Namun, perusahaan dengan utang tinggi akan memiliki risiko keuangan yang tinggi (Darlis dan Zulmi, 2013). Utang yang semakin tinggi dapat membebani perusahaan dengan peningkatan beban keuangan yang bersifat tetap yakni beban bunga yang harus dibayarkan perusahaan. Menurut Setiawan dan Sudiro (2019) adanya utang yang semakin besar akan mengurangi profitabilitas perusahaan.

Karakteristik perusahaan yang lain adalah ukuran perusahaan. Tolak ukur atau total aset digunakan sebagai proksi ukuran perusahaan. Salah satu kelebihan perusahaan yang berukuran besar adalah kemampuan pengelolaan prosedur operasional. Kinerja perusahaan dengan total aset besar (perusahaan berukuran besar) lebih baik dibandingkan dengan perusahaan yang memiliki total aset kecil (perusahaan berukuran kecil). Perusahaan yang berukuran besar memiliki prosedur operasional yang diterapkan sudah terformalisasi dan lebih runtut (Penrose, 1959). Penelitian Setiawan dan Gestanti (2018) menyebutkan bahwa ukuran perusahaan secara positif mempengaruhi kinerja perusahaan. Sehingga, tujuan dari penelitian ini untuk menguji pengaruh corporate governance dan karakteristik perusahaan terhadap kinerja perusahaan manufaktur di Indonesia.

\section{Kajian Literatur}

\section{Corporate Governance dan Kinerja Perusahaan}

Corporate governance diperlukan untuk membantu dalam pengelolaan operasional perusahaan. Menurut OECD (2004) pengertian corporate governance adalah hubungan antara stakeholder, yakni pihak yang mempunyai kepentingan dengan perusahaan. Hal ini berarti, perusahaan harus menerapkan prinsip keadilan, keterbukaan, akuntabilitas, dan pertanggungjawaban dalam memutuskan dan menilai kebijaksanaan yang dilakukan. Melalui penerapan empat prinsip yang menjadi karakter utama dari good corporate governance secara konsisten, benar dan terarah maka diharapkan terselenggaranya landasan, sistem dan mekanisme yang sehat untuk membentuk perilaku perusahaan sehingga akan memberikan pertumbuhan terhadap kinerja perusahaan. Penerapan good corporate governance harus difasilitasi dengan fungsi monitoring yang efektif sehingga perusahaan menggunakan sumberdaya dan melakukan pengambilan keputusan lebih efektif dan efisien .Ukuran dewan komisaris dan proporsi komisaris independen digunakan untuk proksi corporate governance. 


\section{Ukuran Dewan Komisaris}

Adanya teori agensi yang memisahkan kepemilikan dan pengelolaan menjadikan kepentingan pemilik modal menjadi terancam. Hal ini dikarenakan pengelola umumnya menggunakan laba yang diperoleh dari kegiatan operasional untuk kepentingannya sendiri, bukan untuk meningkatkan kekayaan pemegang saham dan perusahaan. Masalah keagenan dapat diatasi salah satunya dengan perusahaan memiliki komisaris yang berfungsi sebagai pengawas kepada manajemen dalam pengambilan keputusan. Berdasarkan Undang-Undang No. 40 Tahun 2007 Pasal 1 ayat 6 mengenai perihal Perseroan Terbatas, dewan komisaris bertugas untuk melakukan pengawasan serta memberi nasihat sesuai dengan anggaran dasar terhadap direksi. Dewan komisaris adalah mekanisme internal untuk mengontrol perilaku oportunistik direksi. Peran dan tugas pengawasan dan pemberian nasihat dapat menyelaraskan kepentingan pemegang saham dan manajemen sehingga akan tercipta good corporate governance. Peningkatan jumlah dewan komisaris menyebabkan pengawasan terhadap direksi semakin ketat, perilaku oportunistik yang dilakukan oleh direksi dapat ditekan sehingga kinerja perusahaan diharapkan meningkat (Al Azhar dan Putri, 2013) :

\section{H1. Ukuran dewan komisaris secara positif mempengaruhi kinerja perusahaan}

\section{Proporsi Komisaris Independen}

Mekanisme internal lain dalam penerapan Good corporate governance ditandai dengan hadirnya komisaris independen dalam anggota dewan komisaris. BAPEPAM mengatur paling sedikit perusahaan harus memiliki $30 \%$ komisaris independen dari total anggota dewan komisaris dengan pertimbangan untuk melindungi kepentingan pemegang saham minoritas.

Komisaris independen digunakan sebagai mekanisme internal penerapan good corporate governance karena mereka dianggap lebih ketat dalam mengawasi manajemen karena mereka lebih objektif dan independen karena tidak memiliki keterkaitan atau afiliasi dengan perusahaan (Gong, Wang dan Yang, 2021). Peran komisaris independen dalam mengawasi maupun memberikan nasihat terhadap dewan direksi akan meningkatkan kinerja perusahaan. Penelitian terdahulu umumnya meneliti pengaruh positif komisaris independen terhadap kinerja perusahaan, seperti yang tampak pada penelitian Liu et.al (2015).

H2. Proporsi komisaris independen secara positif mempengaruhi kinerja perusahaan.

\section{Karakteristik Perusahaan dan Kinerja Perusahaan}

Selanjutnya, karakteristik perusahaan diukur dengan leverage dan ukuran perusahaan. Leverage diukur dengan melihat bagian dana yang berasal dari utang. Leverage terjadi bilamana perusahaan dalam mendanai baik dalam hal operasional perusahaan dan investasi pada suatu proyek menggunakan sumber dana yang menimbulkan beban keuangan yang tetap berupa bunga yakni dengan berhutang (Sudana, 2015:180). Tingginya utang yang dimiliki perusahaan dapat meningkatkan risiko keuangan (Darlis, 2013). Utang yang semakin tinggi dapat membebani perusahaan dengan peningkatan beban bunga yang harus dibayarkan perusahaan.

Tabel 1. Laju Pertumbuhan PDB Industri Manufaktur dalam (\%)

\begin{tabular}{lcccc} 
& $\mathbf{2 0 1 5}$ & $\mathbf{2 0 1 6}$ & $\mathbf{2 0 1 7}$ & $\mathbf{2 0 1 8}$ \\
\hline Indonesia & 4,33 & 4,26 & 4,29 & 4,27 \\
\hline
\end{tabular}

Sumber : Data diolah (2021)

Dari tabel diatas, laju pertumbuhan PDB Industri Manufaktur mengalami tren penurunan dari tahun 2015 hingga 2018,. Suku bunga pinjaman sangat tinggi ketika kondisi ekonomi cenderung memiliki tren penurunan, sementara volume penjualan menurun sehingga menyebabkan laba perusahaan menurun. Hal tersebut dikarenakan kemampuan daya beli masyarakat pada kondisi ekonomi buruk cenderung untuk melemah. Jika dalam kondisi perekonomian yang mengalami tren penurunan namun porsi utang perusahaan meningkat maka perusahaan harus menanggung beban keuangan yang bersifat tetap berupa semakin tingginya beban bunga. Tingginya beban bunga akan menurunkan kinerja perusahaan. Sehingga, sesuai dengan penelitian Setiawan \& Gestanti (2018) maka hipotesis ketiga di dalam penelitian ini adalah:

H3. Leverage secara negatif mempengaruhi kinerja perusahaan. 


\section{Ukuran Perusahaan}

Tolak ukur aset digunakan sebagai proksi ukuran perusahaan. Jika total aset perusahaan semakin besar, maka semakin besar pula ukurannya, vice versa. Salah satu kelebihan perusahaan yang berukuran besar adalah kemampuan pengelolaan prosedur operasional. Prosedur operasional yang diterapkan sudah terformalisasi dan lebih runtut, sehingga hal itu membuat kinerja perusahaan yang lebih besar yang ditandai dengan besarnya total aset akan lebih baik dibandingkan perusahaan total asetnya kecil (Penrose, 1959). Sehingga, sesuai dengan penelitian (Setiawan \& Agustin, 2018) :

\section{H4. Ukuran perusahaan secara positif mempengaruhi kinerja perusahaan}

\section{Metode Penelitian}

Jenis penelitian yang digunakan di dalam penelitian ini adalah kuantitatif eksplanatif. Teknik sampling yang digunakan adalah purposive sampling dengan kriteria sampel yang digunakan adalah perusahaan manufaktur yang terdaftar di Bursa Efek Indonesia (BEI) pada periode 2015-2018 serta menerbitkan laporan keuangan dan laporan tahunan. Terdapat 228 jumlah sampel observasi yang memenuhi kriteria selama tiga tahun penelitian. Teknik analisis data yang diterapkan adalah regresi linier berganda.

Hasil

Data keuangan yang diperoleh peneliti dideskripsikan melalui analisis deskriptif. Analisis deskriptif di dalam penelitian ini meliputi data nilak maksimum, minimum, rata-rata dan standar deviasi dari masing-masing indikator yang digunakan. Berikut adalah hasil analisis deskriptif mengenai indikator yang digunakan di dalam penelitian ini.

Tabel 2 Deskriptif Statistik

\begin{tabular}{llrrrr} 
& & Maximum & Minimum & Rata-Rata & Std Deviasi \\
\hline ROA & .2273 & -.1585 & .0468 & .0499 \\
BSIZE & 12.0000 & 2.0000 & 3.9035 & 1.7857 \\
BINDEP & .6667 & .2000 & .3964 & .0859 \\
FINLEV & & .8824 & .0985 & .4420 & .1868 \\
SIZE & & 14.5375 & 11.1355 & 12.3086 & .6660 \\
Valid N (listwise) & 228 & & & & \\
\cline { 2 - 6 } Sumber : Data diolah (2021) & & & & &
\end{tabular}

Rata-rata nilai kinerja perusahaan yang diukur dengan return on asset (ROA) sebesar 0,0468 atau $4,680 \%$. Nilai minimumnya adalah $-0,1585$ atau $-15,85 \%$ yang artinya selama periode tersebut terdapat perusahaan manufaktur yang mengalami kerugian. Nilai ROA maksimum sebesar 0,2273 atau $22,73 \%$ yang berarti terdapat perusahaan manufaktur yang mampu menghasilkan laba setelah pajak dengan menggunakan total asetnya sebesar $22,73 \%$.

BSIZE mengukur jumlah anggota dewan komisaris. Nilai BSIZE rata-rata sebesar 3,9035. Nilai maksimumnya adalah 12.000 dan nilai minimumnya adalah 2.0000. Rata-rata nilai dari BINDEP sebesar 0,3964. Nilai maksimum adalah 0,6667 dan nilai minimum 0,2000. Rata-rata nilai dari FINLEV sebesar 0,4420. Nilai maksimumnya adalah 0,8824 dan nilai minimumnya adalah 0,0985 . SIZE mengukur ukuran perusahaan yakni logaritma total aset. Rata-rata nilai dari SIZE sebesar 12.3086, nilai maksimum 14.5375 dan nilai minimum 11.1355 .

\section{Gambar 1. Grafik P-Plot Regession untuk Uji Normalitas}

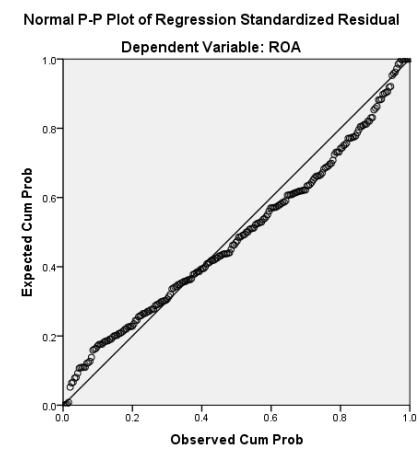

Sumber : Data Diolah (2021) 
Setelah dilakukan analisis deskriptif, selanjutnya dilakukan uji asumsi klasik sebagai syarat dilakukannya uji regresi linear berganda. Uji pertama yang dlakukan dalam pemenuhan asumsi klasik untuk pengujian model regresi adalah uji normalitas. Uji ini diperlukan untuk melihat residual atau nilai sisa dari variabel terdisitribusi secara normal atau tidak. Jika data pengujian tampak disekitar dan mengikuti arah grafik normal P-Plot atau profitability plot regression, maka model dinyatakan lolos uji normalitas. Model regresi 1 dalam penelitian ini menggambarkan bahwa dots atau titik berada disekitar garis diagonal. Jadi, bisa disimpulkan bahwa residual atau nilai sisa dari variabel terdisitribusi secara normal sehingga telah memenuhi syarat uji normalitas seperti yang ditunjukkan dengan gambar 1 di atas.

Selanjutnya dilakukan uji multikolinieritas untuk mengetahui korelasi atau hubungan antar variabel independen. Model fitted regression akan lolos uji multikolinearitas jika antar variabel independen memenuhi asumsi batas ambang nilai. Untuk mengetahui gejala multikolinieritas dapat diamati dari besarnya nilai VIF $>10$ serta Tolerance $<0.10$. Apabila nilai tolerance dan VIF berada di luar dari batas tersebut maka dapat diindikasikan adanya multikolinearitas. Melalui tabel 3 dapat dilihat bahwa hasil pengujian model memnuhi asumsi yang disyaratkan maka tidak terkena gejala multikolinearitas.

Tabel 3. Tabel Multikolinearitas

\begin{tabular}{lcc} 
& Tolerance & VIF \\
\hline BSIZE & 0,556 & 1,799 \\
BINDEP & 0,983 & 1,018 \\
FINLEV & 0,979 & 1,022 \\
SIZE & 0,549 & 1,822 \\
\hline
\end{tabular}

Sumber : Data yang telah diolah (2021)

Menurut Gujarati (1995) bila titik - titik yang ditunjukkan pada hasil grafik, tidak membentuk pola atau gambar yang khas atau scatter plot menyebar, maka uji regresi dikatakan tidak tekena gejala heterokedastisitas. Uji ini untuk melihat terjadinya perbedaan varians dari kesalahan suatu observasi ke observasi yang lain Melalui gambar 2, dapat dilihat bahwa hasil pengujian model 1 menyebar khas sehingga dapat dikatakan bahwa model lolos uji heteroskedastisitas

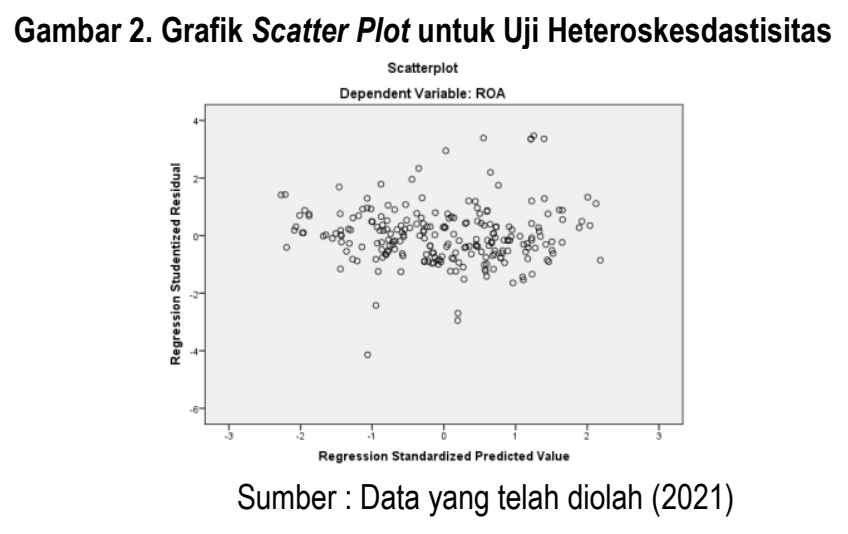

Model regresi yang lolos uji autokerelasi yakni apabila tidak ada keterkaitan antara kesalahan pengganggu periode $\mathrm{t}-1$ dengan kesalahan pengganggu periode t. Model regresi terhindar dari autokorelasi apabila nilai DurbinWatsonTest berada diantara nilai -2 hingga +2 . Hasil tabel 4 model terhindar dari gejala autokorelasi karena $\mathrm{n}$ nilai DWTest adalah 0,542 berada pada batas yang disyaratkan.

Tabel 4. Model Summaryb

\begin{tabular}{cc|c} 
Model & R Square & Durbin-Watson \\
\hline 1 & .253 & .542 \\
\hline
\end{tabular}

Sumber: Data yang telah diolah (2021)

Tabel 5 menunjukkan matriks korelasi yang menggambarkan hubungan atau korelasi antar variabel yang diteliti. Tabel diatas menunjukkan signifikansi dan koefisien korelasi untuk setiap variabel yang dimasukkan ke dalam penelitian. Hasil tersebut bisa digunakan untuk memberikan dukungan awal terhadap hipotesis. 
Tabel 5. Hasil Korelasi

\begin{tabular}{llllll}
\hline & ROA & BSIZE & BINDEP & FINLEV & SIZE \\
\hline ROA & 1,000 & & & & \\
BSIZE & $0,133^{* *}$ & 1,000 & & & \\
BINDEP & $0,126^{*}$ & $-0,62$ & 1,000 & & \\
FINLEV & $-0,401^{* * *}$ & 0,083 & $-0,011$ & 1,000 & \\
SIZE & $0,223^{* * *}$ & $0,660^{* * *}$ & 0,440 & $0,144^{* *}$ & 1,000 \\
\hline
\end{tabular}

Sumber: Data yang telah diolah (2021)

Tabel 6. Hasil Pengujian Hipotesis $\mathrm{t}$

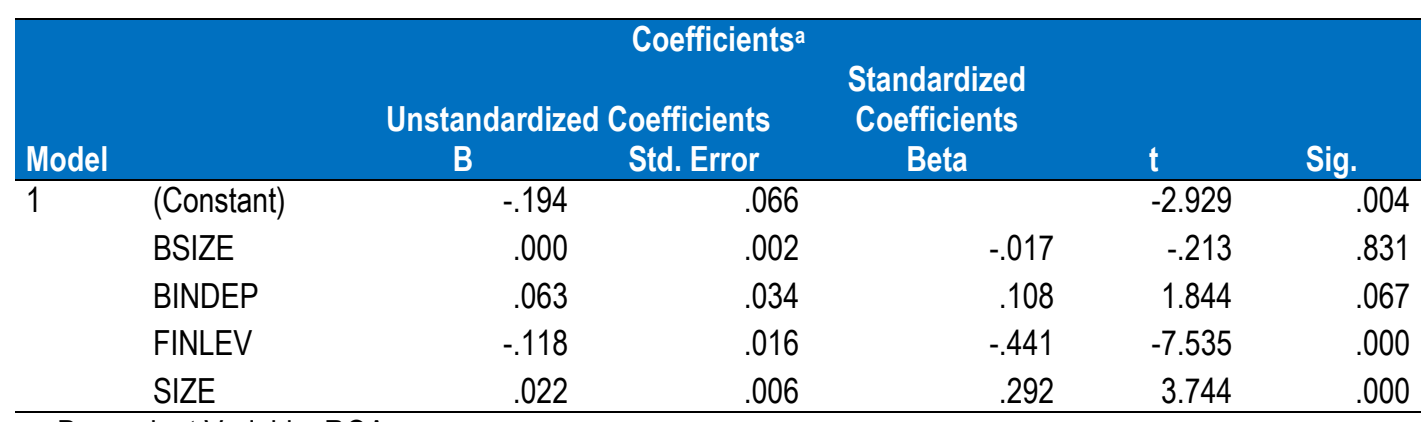

a. Dependent Variable: ROA

Sumber: Data diolah (2021)

Berdasarkan tabel 6, model 1 menunjukkan ukuran dewan komisaris (BSIZE) tidak memengaruhi kinerja perusahaan (ROA). Hal tersebut karena variabel ukuran dewan komisaris memiliki probabilitas sgnifikansi sebesar 0,831 yang berada di atas taraf signifikansi 10\%, akibatnya $\mathrm{HO}$ diterima dan $\mathrm{H} 1$ ditolak. Level of significance untuk variabel proporsi komisaris independen adalah 0,067 nilai ini berada di bawah taraf signifikansi $10 \%$. Sehingga $\mathrm{H} 2$ diterima, leverage (FINLEV) berpengaruh negatif signifikan terhadap kinerja perusahaan (ROA). Level of significance variabel leverage sebesar 0,000 nilai ini berada di bawah level signifikansi $1 \%$, akibatnya $\mathrm{H} 0$ ditolak $\mathrm{H} 3$ diterima. Hal ini artinya, secara positif signifikan ukuran perusahaan mempengaruhi kinerja perusahaan. Level of significance untuk variabel ukuran perusahaan adalah 0,000 nilai ini berada di bawah tingkat signifikansi $1 \%$ sehingga $\mathrm{H} 4$ diterima. Kesimpulan yang dapat ditarik adalah variabel independen yang memiliki pengaruh parsial signifikan terhadap kinerja perusahaan adalah proporsi komisaris independen, leverage dan ukuran perusahaan.

Tabel 7. Hasil Pengujian Hipotesis $\mathrm{F}$

\begin{tabular}{llll} 
Model & & ANOVA $^{\mathrm{a}}$ & Sig. \\
\hline 1 & $\begin{array}{l}\text { Regression } \\
\text { Residual } \\
\text { Total }\end{array}$ & 18.914 & $.000^{\mathrm{b}}$ \\
& & \\
\hline a. Predicted Variable: ROA & \\
\hline b. Predictor Variable: (Constant), BSIZE, BINDEP, FINLEV, SIZE
\end{tabular}

Sumber: Data yang telah Diolah (2021)

Hasil yang terdapat pada tabel 7 , diketahui nilai sigifikansi uji hipotesis $\mathrm{F}$ bernilai 0,000 kurang dari tingkat signifikansi 0,01 artinya terlihat pengaruh variabel independen secara simultan atau bersama-sama terhadap variabel dependen (kinerja perusahaan).

\section{Pembahasan}

\section{Pengaruh Ukuran Dewan Komisaris Terhadap Kinerja Perusahaan}

Variabel ukuran dewan komisaris (BSIZE) ditemukan tidak mempengaruhi kinerja perusahaan (ROA) hal ini dikarenakan koefisien regresi BSIZE atau ukuran perusahaan bernilai negatif namun tidak signifikan. Penelitian (Bennedsen et.al) 2008 menyebutkan bahwa penambahan anggota dewan komisaris berimplikasi ke semakin rendahnya kinerja perusahaan. Jumlah komisaris yang semakin banyak menyebabkan koordinasi antar komisaris sulit sehingga mengakibatkan lambatnya pengambilan keputusan. Sehingga, ukuran dewan komisaris tidak berpengaruh terhadap kinerja perusahaan. Penemuan ini sesuai dengan hasil pelitian Topak (2011) dan Wehdawati (2015) yakni ukuran dewan komisaris tidak berpengaruh terhadap kinerja perusahaan. 


\section{Pengaruh Proporsi Komisaris Independen Terhadap Kinerja Perusahaan}

Variabel proporsi komisaris independen (BINDEP) pada model regresi 1 memiliki koefisien regresi atau bisa disebut beta yang positif dengan taraf signifikansi (a) sebesar 10\% hal itu berarti terdapat pengaruh positif signifikan proporsi komisaris independen terhadap kinerja perusahaan (ROA). Komisaris Independen dijabarkan sebagai seorang komisaris yang tidak memiliki kaitan atau afiliasi dengan controlling shareholders., anggota dewan komisaris, ataupun manajemen dalam perusahan tersebut. Tidak adanya hubungan atau afiliasi tersebut menjadikan komisaris independen memiliki kemampuan untuk bertindak secara independen (Riniati, 2015). Komisaris independen akan mengesampingkan kepentingan pribadi dan lebih objektif dalam memonitor perusahaan serta mencegah perilaku yang hanya mementingkan kepentingan manajemen sehingga mengurangi masalah keagenan. Penelitian Liu et.al (2015) menemukan bahwa peningkatan proporsi komisaris independen berimplikasi pada peningkatan kinerja perusahaan.

\section{Pengaruh Leverage Terhadap Kinerja Perusahaan}

Variabel leverage (FINLEV) pada model regresi 1 memiliki koefisien regresi negatif dengan tingkat signifikansi (a) sebesar $1 \%$ hal itu berarti kinerja keuangan (ROA) dipengaruhi secara negatif dan signifikan oleh variabel leverage (FINLEV). Hal itu berarti semakin besar rasio total hutang terhadap total aktiva, maka semakin kecil kinerja perusahaan (ROA). Hal ini dikarenakan jika jumlah utang perusahaan meningkat maka perusahaan harus menanggung beban keuangan yang bersifat tetap berupa beban bunga yang semakin tinggi. Beban bunga yang semakin tinggi akan menurunkan kinerja perusahaan (Sudana, 2015) dan (Setiawan \& Gestanti, 2018).

\section{Pengaruh Ukuran Perusahaan Terhadap Kinerja Perusahaan}

Variabel ukuran perusahaan (SIZE) pada model regresi 1 memiliki koefisien regresi atau biasa disebut beta yakni positif dengan taraf signifikansi (a) sebesar $1 \%$ hasil ini artinya kinerja perusahaan (ROA) dipengaruhi secara positif oleh ukuran perusahaan. Perusahan berukuran besar memiliki kemampuan pengelolaan prosedur kinerja perusahaan yang sudah terformalisasi sehingga dapat mengelola sumberdaya menjadi efektif dan efisien. Ukuran perusahaan yang semakin besar berimplikasi pada kinerja perusahaan (ROA) yang semakin tinggi. Hal tersebut kemudian, dibandingkan dengan perusahaan - perusahaan berskala kecil, kinerja perusahan besar lebih baik (Penrose, 1959). Hasil penelitian ini selaras dengan penelitian Setiawan \& Agustin (2018) bahwa ukuran perusahaan berpengaruh positif terhadap kinerja perusahaan.

\section{Kesimpulan}

Dari hasil penelitian diatas, dapat disimpulkan bahwa terdapat pengaruh positif signifikan corporate governance yang diproksikan dengan proporsi komisaris independen terhadap kinerja perusahaan. Terdapat pengaruh negatif leverage terhadap kinerja perusahaan dan terdapat pengaruh positif signifikan ukuran perusahaan terhadap kinerja perusahaan. Dengan demikian perlu bagi perusahaan manufaktur agar senantiasa memperhatikan corporate governance yang terbukti memiliki pengaruh positif dan signifikan terhadap kinerja perusahaan, serta mengatur hutang perusahaan karena hal tersebut juga memiliki dampak negatif bagi perusahaan. Saran untuk penelitian selanjutnya adalah menambahkan pengukuran lain terhadap kinerja perusahaan, seperti kinerja pasar (Tobin's Q) sehingga pembahasan topik pengaruh corporate governance (tata kelola perusahaan) dan karakteristik perusahaan terhadap kinerja perusahaan menjadi lebih komprehensif.

\section{Daftar Pustaka}

Al Azhar, A., \& Putri, D. E. (2013). Analisis Karakteristik Perusahaan Yang Mempengaruhi Kinerja Keuangan Perusahaan. PEKBIS (Jurnal Pendidikan Ekonomi Dan Bisnis), 5(3), 190-201.

Bennedsen, M., Kongsted, H. C., \& Nielsen, K. M. (2008). The causal effect of board size in the performance of small and medium-sized firms. Journal of Banking and Finance, 32(6), 1098-1109. https://doi.org/10.1016/j.jbankfin.2007.09.016

Darlis, E., \& Zulmi, N. (2013). Pengaruh Ukuran Dewan Komisaris, Tingkat Leverage Dan Tingkat Profitabilitas Terhadap Pengungkapan Informasi Lingkungan Hidup (Studi Empiris Pada Laporan Keuangan Perusahaan Rawan Lingkungan Yang Listing di BEJ Periode 2004-2006). Jurnal Ekonomi, 17(03). 
Gong, M., Wang, Y., \& Yang, X. (2021). Do independent directors restrain controlling shareholders' tunneling? Evidence from a natural experiment in China. Economic Modelling, 94, 548-559.

Hasnati. (2003). Analisis hukum komite audit dalam organ perseroan terbatas menuju good corporate governance. Jurnal Hukum Bisnis, 22(6), 16-24.

Liu, Y., Miletkov, M. K., Wei, Z., \& Yang, T. (2015). Board independence and firm performance in China. Journal of Corporate Finance, 30, 223-244.

Martsila, I. S., \& Meiranto, W. (2013). Pengaruh Corporate Governance Terhadap Kinerja Perusahaan. Diponegoro Journal of Accounting, 2(4), 1-14.

Nomor, U. U. R. I. (40). tahun 2007 tentang Perseroan Terbatas.

OECD, O. (2004). The OECD principles of corporate governance. Contaduría y Administración, (216).

Penrose, E. T. 1959/1995. The Theory of the Growth of the Firm, 3rd ed. Oxford University Press, Oxford, UK

Riniati, K. (2015). Pengaruh Komisaris Independen dan Komite Audit Terhadap Kinerja Perusahaan. In Program Studi Akuntansi Fakultas Ekonomi Universitas Negeri Yogyakarta. https://doi.org/10.1377/hlthaff.2013.0625

Setiawan, R., \& Agustin, R. (2018). Industrial Diversification and Firm Performance of Manufacturing: Does Efficiency Matter? Trikonomika, 17(2), 72. https://doi.org/10.23969/trikonomika.v17i2.1146

Setiawan, R., \& Gestanti, L. (2018). CEO Education, Karakteristik Perusahaan dan Kinerja Perusahaan. Jurnal IImiah Manajemen, 2(2), 101-109. https://doi.org/10.1017/CBO9781107415324.004

Setiawan, R., \& Sudiro, K. (2019). Struktur modal dan profitabilitas perusahaan anggota. Journal Ekonomi Dan Bisnis, 23(1), 37-46.

Sudana, I. M. (2015). Teori dan Praktik Manajemen Keuangan Perusahaan. Jakarta: Erlangga.

Topak, M. S. (2011). The effect of board gender diversity on firm performance: evidence from Turkey. Middle Eastern Finance and Economics, 14. https://doi.org/10.1108/GM-10-2015-0088

Wehdawati;, Swandari, F., \& Jikrillah, S. (2015). Pengaruh Mekanisme Good Corporate Governance Dan Struktur Kepemilikan Terhadap Kinerja Keuangan Perusahaan Manufaktur Yang Terdaftar Di Bei Tahun 20102012. Jurnal Wawasan Manajemen, 3(3), 205-216.

www.idx.co.id 